\title{
ダム貯水池における土砂バイパス施設の 分派特性の検討 \\ DIVERSION PROPERTIES OF SEDIMENT BYPASS FACILITIES USING THREE-DIMENSIONAL SEDIMENT TRANSPORT MODEL
}

\author{
久保田踊児 1 ・米山望 2 -角哲也 3 \\ Yoji KUBOTA, Nozomu YONEYAMA and Tetsuya SUMI \\ 1正会員 工修 株式会社ハイドロソフト技術研究所（†530-6126 大阪市北区中之島3-3-23-26F） \\ 2正会員 博士（工）京都大学防災研究所 流域災害研究センター（下611-0011 京都府宇治市五ヶ庄） \\ 3正会員 博士（工）京都大学防災研究所 水資源環境研究センター（†611-0011 京都府宇治市五ヶ庄）
}

\begin{abstract}
Regarding sediment bypassing operation, real case study is very limited to only Miwa dam or Koshibu Dam in the Tenryu river. Therefore, further study is needed in order to assess quantitative efficiency of sediment bypassing based on reservoir geometry, hydraulic conditions and deposited sediment property. We have developed a three-dimensional sediment transport model that can calculate the bed deformation and complex flow around the diversion facility. We compared the numerical and experimental results on diversion facilities and confirmed the validity of the model. Using this model, we performed calculations by varying the particle size of sediment, the slit width of diversion facility and flow rate. Based on these calculation results, we investigated three dimensional effects on sediment deposition and discharging process from upstream of diversion weir to sediment bypass tunnel. Finally, we have discussed sediment bypassing ratio and proposed empirical equations with sediment properties and diversion facilities.
\end{abstract}

Key Words : reservoir sedimentation, sediment bypassing, three-dimensional sediment transport model

\section{1.はじめに}

貯水池の持続性と流砂系の連続性の両立を目的とし た土砂管理手法として，フラッシング排砂や排砂バイパ ス等，下流に土砂を流下させる対策が進められている. 排砂バイパスについては，新宮川水系旭ダム，天竜川水 系美和ダム等で実施されており，同じ天竜川水系の小渋 ダム，松川ダムでも導入が進められている，旭ダム，美 和ダムについてはバイパス完成後のモニタリング調査に より, 排砂効果と貯水池内の濁水低減効果が確認されて いる. 排砂バイパス施設は, 出水時の土砂を含む流れの 一部を，貯水池を迂回して流下させ，堆砂容量の低減を 図ろうとするものである．施設は，貯水池上流端付近で 流水および流水中の土砂を分派する分派堰と，分派した 流水および土砂をダム直下まで導水するバイパストンネ ルにより構成され，トンネル出口には必要に応じて減勢 工が設けられる（図-1参照）。排砂バイパスは，土砂の 輸送エネルギーとして貯水池区間を流下寸る流れのエネ ルギーを利用するものであり，機械による掘削等の別の 土砂輸送エネルギーを必要としない方策として，今後の
発展が期待されている．排砂バイパス施設が有する課題 については角ら1によって整理されており，その中で， 将来的に土砂管理が必要になる可能性があるダムについ ては，新規建設の段階から効率的な排砂バイパス施設整 備を行う必要があることが指摘されている. 排砂バイパ ス施設の内，分派施設では，少ない流量でより多くの流 入土砂を分派できることが施設設計上の要点となる。ま た, バイパストンネルでは, 分派された流水を下流にス ムーズに導水させることが重要となる.

分派施設に関する既往の研究として，川合ら 2)はY型 分岐直線水路と湾曲分岐水路を用いた固定床実験を行い, 流路の分岐による掃流砂量配分比は流量配分と偏角に よって定まることを示し，両者の関係式を求めている.

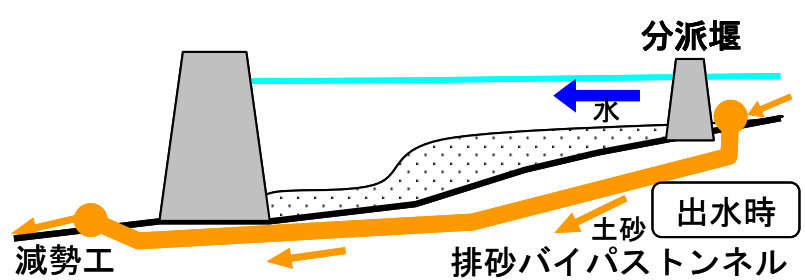

図-1＼cjkstart排砂バイパス施設の模式図 


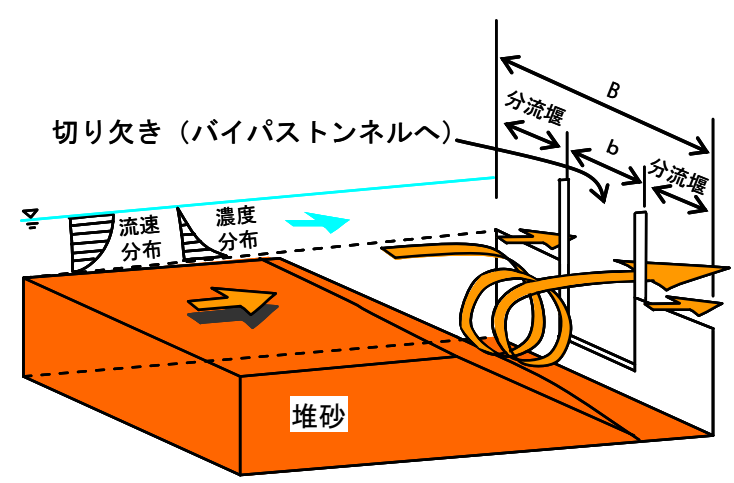

図-2 分派堰上流のらせん流の形成 ${ }^{3)}$

柏井ら ${ }^{3)}$ は，分派堰に関して掃流砂を対象に水理 模型実験を行い，図-2のように分派堰上流において らせん流が形成されること, 粒径が大きいほど, 濃 度分布が底面付近に偏る為, 分流する流れの選択に より, 少ない水量の分流で多くの土砂を捕捉しバイ パストンネルに導流できることを示している．また， バイパストンネルに関する既往の研究として, 原田 ら4) は, 水理模型実験により, バイパストンネル内 の土砂水理特性について検討し, 土砂流入時のトン ネル内堆積により, トンネル内に負圧を伴う大きな 圧力変動が生じる可能性があることを示すとともに, 圧力変動は, トンネル内の堆砂による導水勾配の差 によるものであることを示している.

上述の研究により, 排砂バイパス施設の土砂輸送 のメカニズムは明らかにされてきているが，より効 率的な土砂の分派・排砂を可能と寸る施設設計を行 う為には，上流からの流入量や流入土砂の粒度分布, 分派堰の形状等の違いによって, 分派効率がどのよ うに変化するのかを明らかにする必要がある。特に, 出水時の分派堰周辺では, 図-2に示すように堆砂肩 部より堰の切り欠き部に向から複雑な流動が発生し ており, これらの3次元的な流動および土砂移動を 詳細に検討寸るには, 現在汎用的に用いられている 平面 2 次元河床変動モデルでは再現が困難である.

そこで本研究では, 筆者らの提案する3次元河床 変動モデルを用いて, 分派堰周辺の複雑な流動と地 形変化を解析し, 過去に行われたダム貯水池の分派 施設の水理模型実験結果との比較 - 検証を行う. 検 証により解析モデルの有効性を確認した上で，分派 堰の切り欠き幅, 流量, 土砂の粒径を変化させた予 測解析を行い, 流量と土砂の分派特性（捕捉率）を 明らかにするとともに, 分派施設・土砂条件より分 派特性を簡易的に算出可能な回帰式を提示寸る.

\section{2. 解析モデル概要}

本研究では, 米山らが開発したレイノルズ平均ナ ビエ・ストークス方程式を基礎方程式とする3次元 の非静水圧解析モデル5)をベースとし, 河床変動過 程を組み込んだ解析モデルを構築した。流動場の解
析モデルの基礎式である連続式(1)および運動方程 式(2)を以下に示す。基礎式は, テンソル表記にお けるアインシュタインの総和規約で記述している.

$$
\begin{gathered}
\frac{\partial u_{i}}{\partial x_{i}}=0 \\
\frac{\partial u_{i}}{\partial t}+u \frac{\partial u_{i}}{\partial x_{j}}=f_{i}-\frac{1}{\rho} \frac{\partial p}{\partial x_{i}}+v \frac{\partial^{2} u_{i}}{\partial x_{j} \partial x_{j}}+\frac{1}{\rho} \frac{\tau_{i j}}{\partial x_{j}}
\end{gathered}
$$

ここに, $u_{i}(i=1,2,3)$ : 平均流速成分, $x_{i}$ : デカル 卜座標 $(x, y, z)$ 成分, $\rho$ : 水の密度, $v$ : 動粘性係数, $p$ : 圧力, $f_{i}$ : 体積力, $\tau_{i j}$ : レイノルズ応力であ る.レイノルズ応力については, 標準 $k-\varepsilon$ モデル の線形方程式で表される. 貯水池および河川への適 用を考慮し，土砂の分級過程および河床の粗粒化や， 細粒化現象を表現できるように，混合砂砂モデルを 導入し，粒径毎に流砂量を計算する。流砂の移動に ついては, 掃流砂, 浮遊砂を考慮する. 浮遊砂につ いては, 濁質挙動に関する既往研究6)を参考に浮 上・沈降過程および非定常の3次元移流拡散方程式 を解く非平衡モデルとする. 河床高の変化について は, 各粒径毎, 流砂形態毎に求められた流砂量を用 いて式(3)に示寸流砂の連続式により計算する.

$$
\frac{\partial z_{b}}{\partial t}=\frac{-1}{(1-\lambda)} \sum_{k}\left\{\frac{\partial B q_{b x k}}{\partial x}+\frac{\partial B q_{b y k}}{\partial y}+\left(E_{s k}-D_{s k}\right)\right\}
$$

ここに, $z_{b}$ : 河床高, 添字 $k$ : 粒径階,

$q_{b x k}: x$ 方向の粒径階 $k$ の単位幅掃流砂量,

$q_{b y k}: y$ 方向の粒径階 $k$ の単位幅掃流砂量,

$E_{s k}, D_{s k}:$ 粒径階 の浮遊砂の浮上量と沈降量 である。

河床材料変化については, 図-3に示寸交換層・遷 移層・堆積層の粒度分布の鉛直方向変化を考慮した 芦田・江頭・劉らの多層モデル7)を用いる. 以上をまとめ, 表-1にモデル構成を示す.

表-1 モデル構成

\begin{tabular}{|l|l|}
\hline ベースモデル & 3次元非静水圧密度流解析モデル \\
\hline 水面の取り扱い & VOF法 (Volume of Fluid) \\
\hline 乱流モデル & 標準 $k-\varepsilon$ モデル \\
\hline 土砂移動形態 & 掃流砂, 浮遊砂の形態を考慮 \\
\hline 砂礫モデル & 複数粒径の混合砂礫モデル \\
\hline 掃流砂・浮遊砂式 & 芦田・道上式 \\
\hline 河床高変化 & 流砂の連続式 \\
\hline 河床材料変化 & $\begin{array}{l}\text { 交換層, 遷移層, 堆積層の概念を導 } \\
\text { 入した粒度分布の多層モデル }\end{array}$ \\
\hline 側方侵食 & $\begin{array}{l}\text { 水中安息角以上となった場合に, 土 } \\
\text { 砂のずり落ち過程を考慮 }\end{array}$ \\
\hline
\end{tabular}




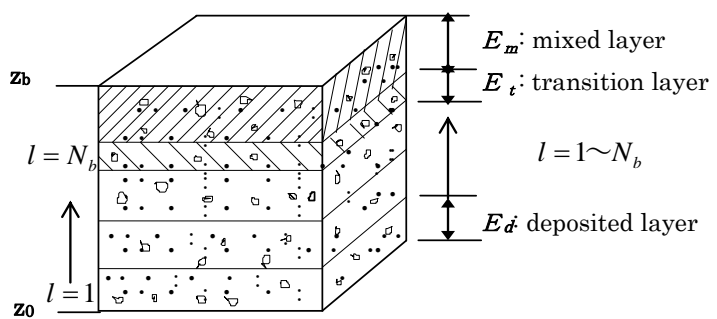

図-3＼cjkstart粒度分布多層モデルの模式図

また，本モデルには側方侵食が考慮されており， 河床勾配が水中安息角以上になった場合に, 堆砂肩 からの土砂のずり落ち過程を再現することが可能で ある. 本検討では，対象となる土砂の粒径を勘案し， 水中安息角を $30^{\circ}$ に設定している.

\section{3. 水理模型実験結果を用いた分派施設の 検証解析}

小渋ダムの水理模型実験結果8)との比較検証を 行った。表-2に計算条件, 図-4に地形条件を示す。 実験水路の縮尺は1/50である。ここでのポイントは， 分派の仕組みとして，中央の切り欠き部を通る水と 土砂がバイパストンネルに導流され，両側の袖部を 越流した水と土砂がダムに導流される構造になって いることで，切り欠き幅を変化させた場合の分派特 性の変化である. なお，通常の分派堰は，切り欠き 部を分派堰の側方に設ける場合もあるが，本検討で は既存の水理模型実験のレイアウトに従い堰中央部 に設置した．また給砂については，河道上流端の河 床形状が維持されるように平衡給砂量を与えた。

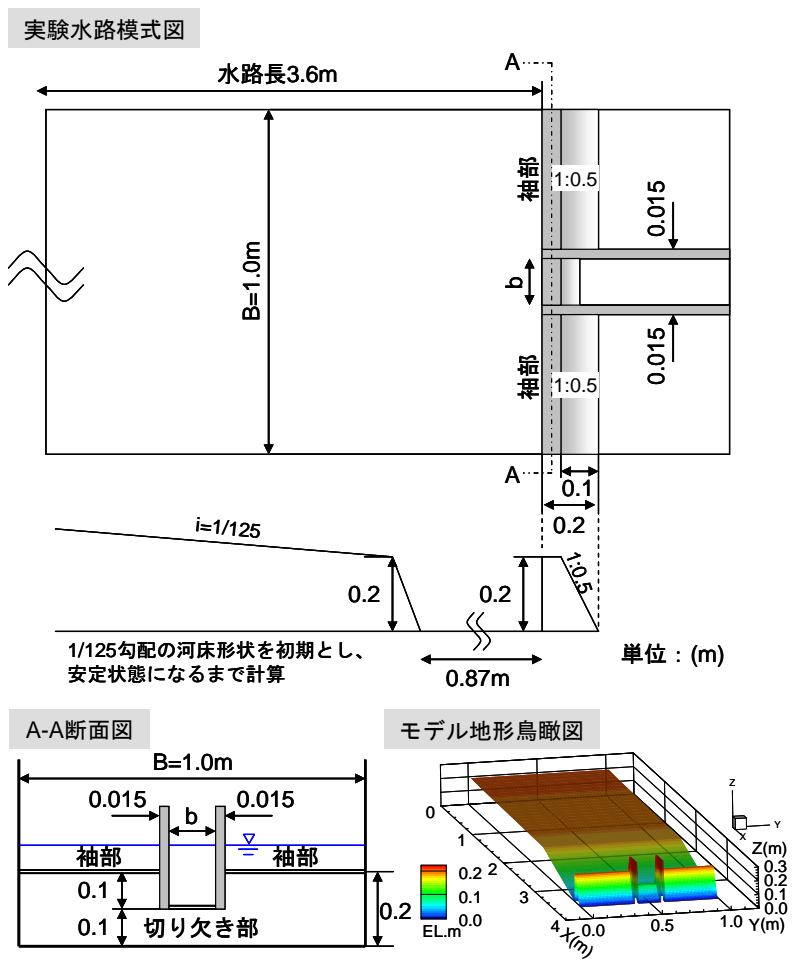

図-4 地形条件 表-2（a）計算条件（共通）

\begin{tabular}{|c|c|}
\hline 項目 & 条件 \\
\hline \hline 計算期間 & 2時間（助走計算1時間含む） \\
\hline 計算区間 & 分派堰〜上流 : $3.6 \mathrm{~m}$ \\
\hline 総メッシュ数 & 286,720 \\
\hline メッシュ間隔 & $\Delta x: x=0.0 \sim 1.5 \mathrm{~m}: 0.02 \mathrm{~m}$ \\
& $x=1.5 \sim 1.9 \mathrm{~m}: 0.03 \sim 0.08 \mathrm{~m}$ \\
& $x=1.9 \sim 3.6 \mathrm{~m}: 0.10 \mathrm{~m}$ \\
& $\Delta y: y=0.0 \sim 0.4 \mathrm{~m}: 0.02 \mathrm{~m}$ \\
& $y=0.4 \sim 0.6 \mathrm{~m}: 0.01 \mathrm{~m}$ \\
& $y=0.6 \sim 1.0 \mathrm{~m}: 0.02 \mathrm{~m}$ \\
& (分派壁のみ $0.015 \mathrm{~m})$ \\
& $\Delta z: 0.01 \mathrm{~m}$ \\
\hline
\end{tabular}

(b) 計算条件（ケース別）

\begin{tabular}{|c|c|c|c|c|}
\hline ケース & $\begin{array}{c}\text { 平均粒径 } \\
(\mathrm{mm})\end{array}$ & $\begin{array}{c}\text { 切り欠き幅 } \\
(\mathrm{m})\end{array}$ & $\begin{array}{c}\text { 流量 } \\
\mathrm{l} / \mathrm{s}\end{array}$ & $\begin{array}{c}\text { 給砂量 } \\
\mathrm{cm}^{3} / \mathrm{s}\end{array}$ \\
\hline $3-1$ & 0.44 & 0.07 & 40 & 189 \\
\hline $3-2$ & 0.44 & 0.13 & 40 & 189 \\
\hline $3-3$ & 0.44 & 0.17 & 40 & 189 \\
\hline
\end{tabular}

\section{（1）流動・地形変化の検証}

図-5に，切り欠き幅を変化させた場合の通水1時 間後の河道中央（ $\mathrm{Y}=0.5 \mathrm{~m} ）$ における流速ベクトル の比較を示す. 切り欠き幅の最も大きい $\mathrm{b}=0.17 \mathrm{~m}$ の ケースでは, 堆砂面と分派堰の間から上昇し, 切り 欠き部に向から流れが形成されている.

図-6に通水 1 時間後の河道中央 $(\mathrm{Y}=0.5 \mathrm{~m})$ にお ける河床高縦断を示す。実験結果は $1 \mathrm{~m}$ 間隔の河床 データしかないものの，計算結果は実験結果の縦断 的な侵食状態を概ね再現できている。計算では分派 堰の始端からの距離 $\mathrm{X}=-0.5 \mathrm{~m}$ 付近に堆砂の肩部が 形成されていることがわかる。計算による堆砂の進 行過程は以下の通りであった（図-7参照）。

(1) 段丘肩まで掃流状態で進行してきた砂は，段 丘肩からずり落ちて水中安息角で堆砂する。

(2)切り欠き部に向かって流れ方向に鉛直下向き のらせん流が発生する。

(3) 段丘肩の下の砂は, らせん流によって巻き上 げられ，分派堰より排出される.

上記の土砂のずり落ち過程，らせん流の形成およ び巻き上げによる分派堰からの排砂過程は，3次元 の複雑な流動場を解析できる数值モデルによって初 めて再現可能な現象である。図-8に分派堰近傍の流 動場のスナップショットを示す。眓中の流線より, 水路法面から切り欠き部に向かってらせん流が発生 していることが確認できる.

図-9に通水期間内で平均した切り欠き部および袖 部からの排砂量の比較を示す. 切り久き部の拡大に 伴う排砂量の増加傾向が計算でも再現されている. 


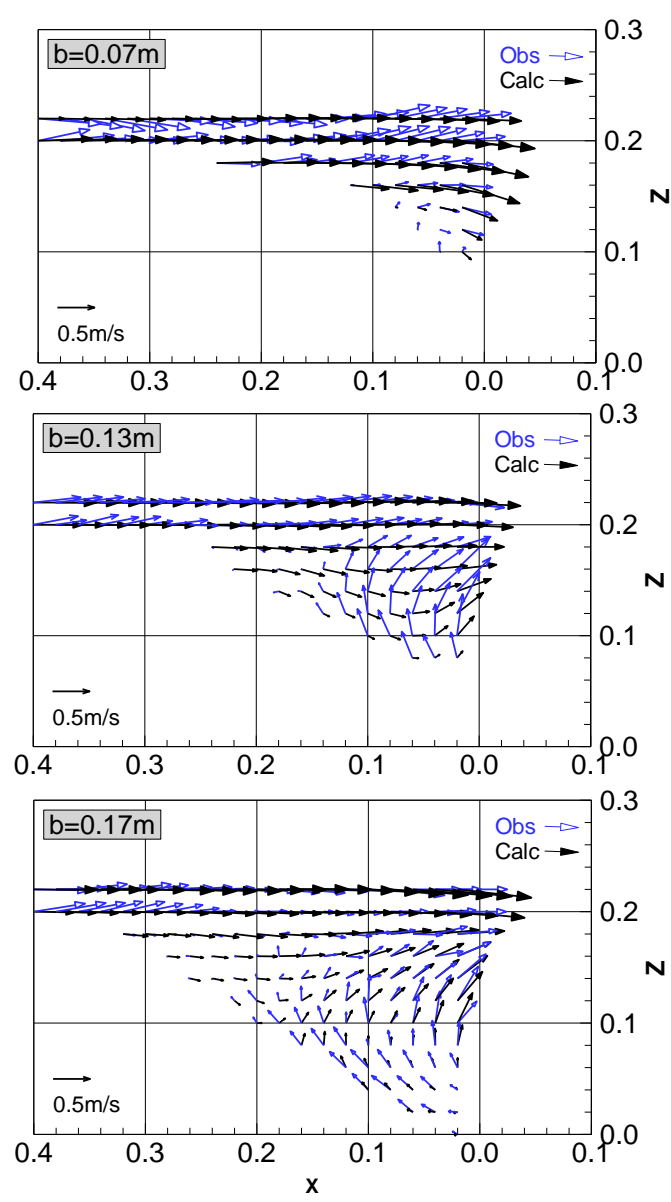

図-5 流速ベクトルの空間分布の比較 $\mathrm{Y}=0.5 \mathrm{~m}$, 通水 1 時間後

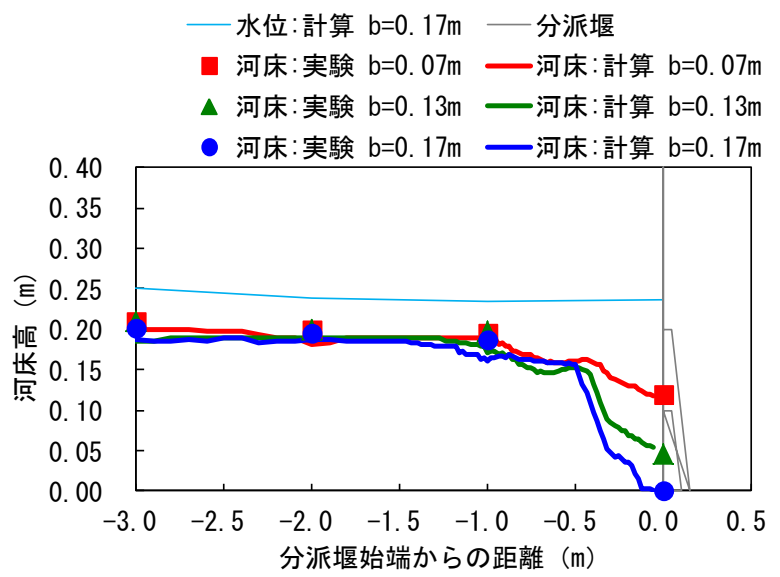

図-6 河床縦断の比較（ $\mathrm{Y}=0.5 \mathrm{~m}$ ，通水1時間後）

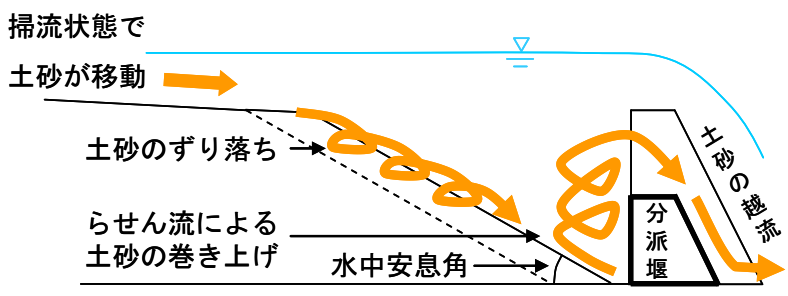

図-7 堆砂の進行過程の模式図

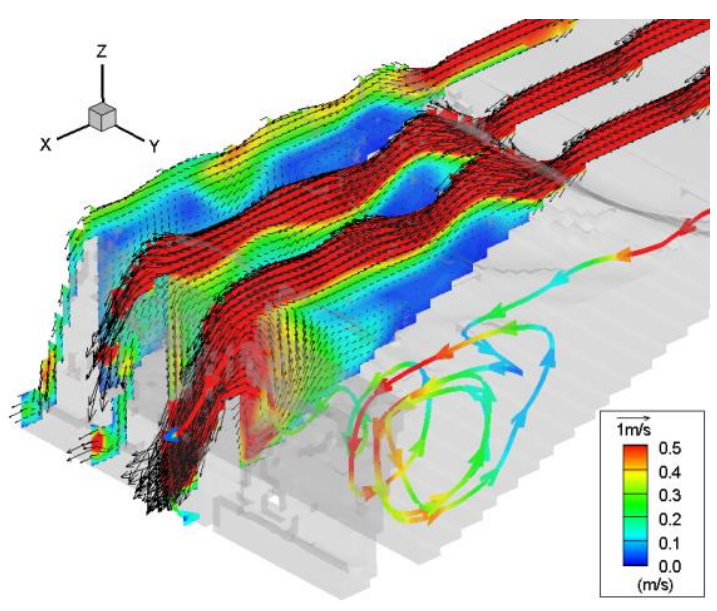

図-8 流動場の3次元鳥瞰図

下流に向かって左半分：流線表示,

右半分：流速ベクトル・コンターの縦断面表示

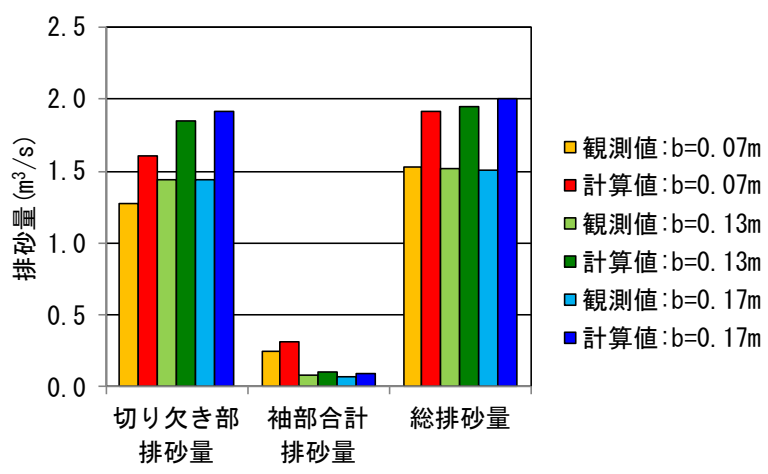

図-9 排砂量の比較

\section{（2）分派特性の検証}

水と土砂の分派特性について，実験時の分派堰周 辺の土砂移動の観測を行い，下記の2点を考慮した 柏井 ${ }^{2)}$ の方法に基づき，流量の捕捉率 $\alpha$ と土砂捕 捉率 $r$ を用いて検討を行う。

(1) 堆砂の肩部までは堆砂面上を一様に土砂が流 下し，その後，堰の切り久き部と袖部への分 派が発生する。

(2)切り欠き部へ向かう土砂は，ほぼ全量がその まま越流すると考えられる。

堆砂肩の断面上で堰の袖部へ向かう土砂量を $Q_{s 1}$, 堰の袖部を越流する土砂量を $Q_{s 2}$ とすると, 土砂捕 捉率 $r$ は式(4)で定義される。また，流量の捕捉率 $\alpha$ についても同様に，堆砂肩の断面上で堰の袖部 へ向から流量を $Q_{w 1}$, 堰の袖部を越流する流量を $Q_{w 2}$ として，式(5)で定義される.

$$
r=1-\frac{Q_{s 2}}{Q_{s 1}} \quad(4), \quad \alpha=1-\frac{Q_{w 2}}{Q_{w 1}}
$$


図-10に式(4)，式(5)で示される流量の捕捉率 $\alpha$ と土砂捕捉率 $r$ の比較結果を示す. 図より, 切り欠 き幅が小さいほど, 流量の捕捉率が小さくなり，こ れに伴って土砂の捕捉率も低下していることがわか る. 流量の捕捉率および流砂の捕捉率の計算值と実 験值が概ね整合していることから, 分派堰からの土 砂の排出過程が適切に計算されていると考えられる. 最も捕捉率の低下している切り久き幅 $\mathrm{b}=0.07 \mathrm{~m}$ の ケースに着目すると, 流量の捕捉率は 0.2 弱である のに対し，土砂の捕捉率は 0.8 程度となっている. このように, 少ない分派流量でより多くの土砂を捕 捉し，バイパストンネルへ流送できることが分派堰 のメリットである。

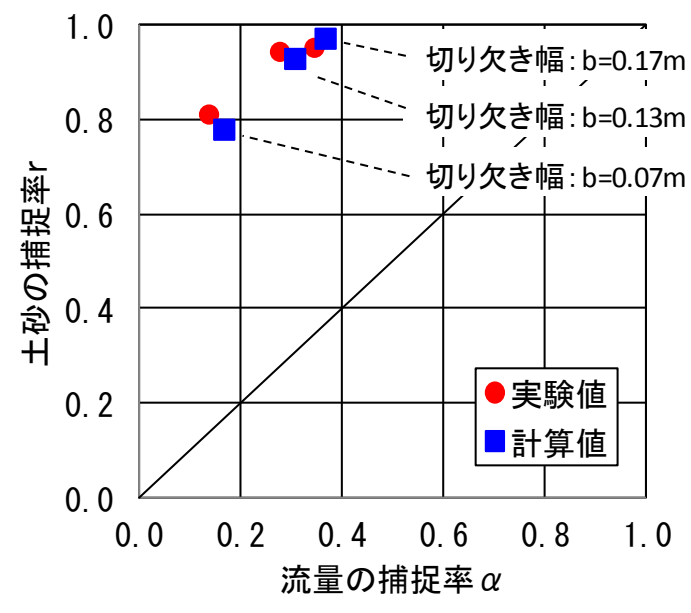

図-10 流量と土砂の捕捉率の比較

\section{4. 分派施設の分派効率の検討}

\section{（1）切り欠き幅・平均粒径の違いによる検討}

検証計算により，再現性が確認された解析モデル を用いて, 土砂の粒径, 切り欠き幅, 流量のパラ メータを変更した予測計算を行い，各パラメータが 流量および土砂の捕捉率に与える影響について検討 を行った。表-3に計算条件を示す。

分派施設の効率を検討する上で重要となるのが, 分派流量が少ない場合の土砂の捕捉率の変化である. この為, 流量の捕捉率 $\alpha$ が 0.2 を下回る領域での土 砂の捕捉率の変化を示した計算結果は, 排砂効率向 上の為の重要な参考データとなる.

図-11に予測計算全ケースの流量の捕捉率と土砂 の捕捉率の関係を示す. 図より, 沈降速度 $w_{0}$ と摩 擦速度 $u_{*}$ の比が大きいほど, 土砂の捕捉率が高く なることがわかる. 捕捉率の増加のメカニズムにつ いて, 粒径が大きいほど, 底部を掃流状態で土砂が 流れる為, らせん流により堰の切り欠き部に切り欠 き幅以上の土砂がかき集められることにより土砂の 捕捉率が高くなると考えられる. また, 流量の捕捉 率が 0.2 を下回ると急激に土砂の捕捉率が低下して いることがわかる。
表-3 計算条件

\begin{tabular}{|c|c|c|c|c|c|}
\hline ケース & $\begin{array}{c}\text { 平均粒径 } \\
(\mathrm{mm})\end{array}$ & $\begin{array}{c}\text { 切り欠き幅 } \\
(\mathrm{m})\end{array}$ & $\begin{array}{c}\text { 流量 } \\
\mathrm{l} / \mathrm{s}\end{array}$ & $\begin{array}{c}\text { 給砂量 } \\
\mathrm{cm}^{3} \mathrm{~s}\end{array}$ & $\begin{array}{c}\text { 沈降速度 } \cdot \\
\text { 摩擦速度比* }\end{array}$ \\
\hline $1-1$ & 0.16 & 0.07 & 40 & 192 & 0.417 \\
\hline $1-2$ & 0.16 & 0.13 & 40 & 192 & 0.417 \\
\hline $1-3$ & 0.16 & 0.17 & 40 & 192 & 0.417 \\
\hline $1-4$ & 0.16 & 0.13 & 20 & 92 & 0.508 \\
\hline $1-5$ & 0.16 & 0.17 & 20 & 92 & 0.508 \\
\hline $1-6$ & 0.16 & 0.04 & 20 & 92 & 0.508 \\
\hline $2-1$ & 0.31 & 0.07 & 40 & 87 & 0.863 \\
\hline $2-2$ & 0.31 & 0.13 & 40 & 87 & 0.863 \\
\hline $2-3$ & 0.31 & 0.17 & 40 & 87 & 0.863 \\
\hline $2-4$ & 0.31 & 0.04 & 40 & 87 & 0.863 \\
\hline $3-1$ & 0.44 & 0.07 & 40 & 189 & 1.118 \\
\hline $3-2$ & 0.44 & 0.13 & 40 & 189 & 1.118 \\
\hline $3-3$ & 0.44 & 0.17 & 40 & 189 & 1.118 \\
\hline $3-4$ & 0.44 & 0.04 & 40 & 189 & 1.118 \\
\hline
\end{tabular}

※沈降速度 : Rubey式により算出. 摩擦速度 : 接近流速より算出.

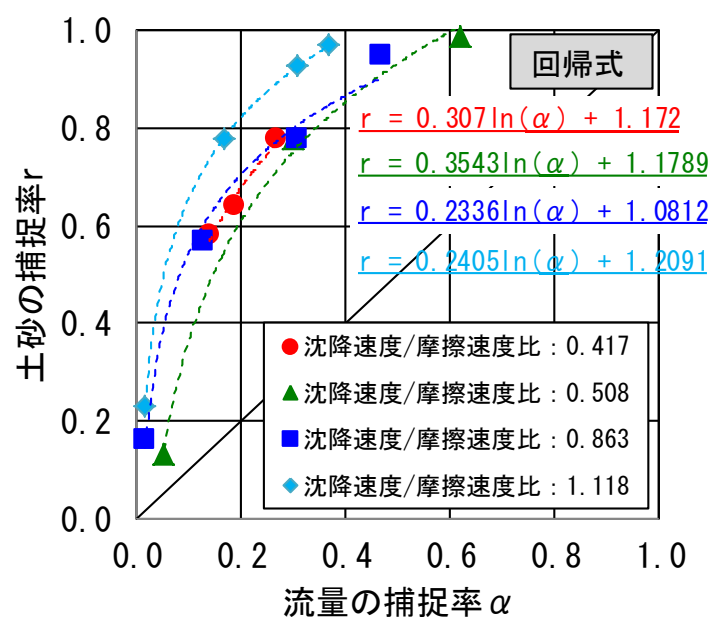

図-11 流量と土砂の捕捉率の関係 各沈降速度 ·摩擦速度比毎の回帰式を図中に表示

\section{(2) 回帰式の提示}

予測計算によって得られた捕捉率を基に，以下の 手順で土砂の捕捉率を流量の捕捉率と沈降速度・摩 擦速度比から簡易的に算出できる回帰式を求めた。

(1) 流量の捕捉率を与条件として，土砂の捕捉率 を算出する回帰式を求める。回帰式は沈降速 度・摩擦速度比毎に分けて作成する。回帰式 の分布形については，流量と土砂の捕捉率の 分布を良好に再現している対数分布を仮定し， 回帰式を作成する（図-11参照）。

(2) 回帰式の係数である $\alpha_{d}, \beta_{d}$ を沈降速度・摩擦 速度比 $w_{0} / u_{*}$ の関数で表現する. 関数の分布 形は，分布の適合度よりもモデル化の簡便さ を優先し，線形近似とする（図-12参照）.

上記の方法で求められた回帰式を式(6)に示す. 
土砂の捕捉率 $r=\alpha_{d} \ln \alpha+\beta_{d}$

$$
\begin{gathered}
\alpha_{d}=A_{d 1} \times\left(w_{0} / u_{*}\right)+B_{d 1} \\
\beta_{d}=A_{d 2} \times\left(w_{0} / u_{*}\right)+B_{d 2} \\
A_{d 1}=-0.1449, \quad B_{d 1}=0.3904 \\
A_{d 2}=0.0019, \quad B_{d 2}=1.1589
\end{gathered}
$$

ここに, $\alpha$ : 流量の捕捉率, $w_{0} / u_{*}$ : 沈降速度 摩擦速度比である. また, より簡易的な回帰式とし て, 捕捉率と切り欠き幅の比率との間に対数関係を 仮定し, 回帰式を求めた. 図-13に水路幅と切り欠 き幅の比 $b / B$ と土砂の捕捉率 $r$ の関係を示寸. 回帰 式は以下の式(7)で表される.

$$
\begin{aligned}
& r=\delta \ln (b / B)+\eta \\
& \delta=0.4782, \quad \eta=1.7852
\end{aligned}
$$

ここに， $\delta, \eta:$ 回帰式の係数である. 式(7)に よって, 分派堰の水路幅に対する切り欠き幅を与条 件として, 土砂の捕捉率を簡易的に算出することが 可能である.

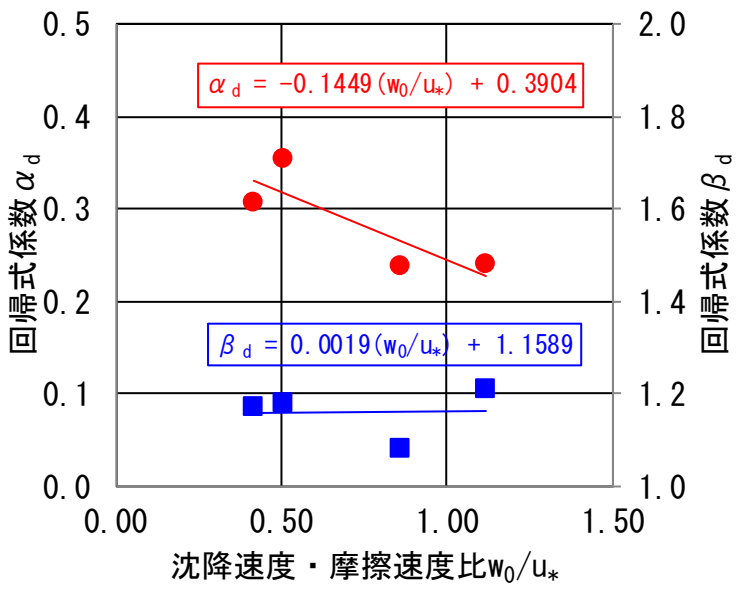

図-12 沈降速度・摩擦速度比と回帰式係数の関係

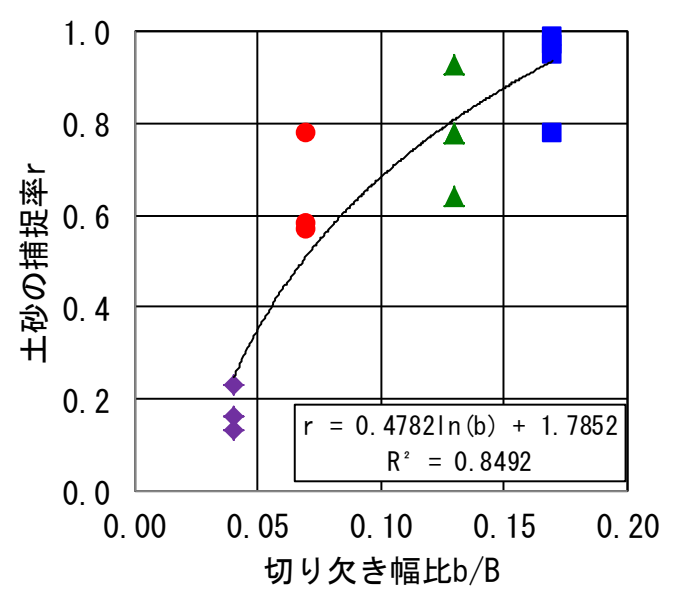

図-13 切り欠き幅比と土砂の捕捉率の関係

\section{5. 結語}

貯水池の土砂バイパス施設のうち, 分派堰の分 派効率について, 3次元河床変動モデルを用い, 分 派施設の水理模型実験結果との比較検証を行い, 分派堰の形状や土砂の粒度, 流量条件による分派 効率の違いについて検討し, 以下の結論を得た。

(1) 過去の分派施設の水理模型実験結果を用いて 3 次元の流動・地形変化計算の検証を行った結 果, 分派堰直上でのらせん流の形成, 土砂の ずり落ち過程, 土砂の巻き上げ・排出過程が 再現され, 解析モデルの妥当性が示された。

(2) 土砂の粒径, 切り欠き幅, 流量を変更した予 測計算を行い, 既往の研究では不明瞭であっ た分流量の小さな領域を含む流量の捕捉率と 土砂の捕捉率の関係を示した。

(3) 流量の捕捉率, 沈降速度 ・摩擦速度比および 切り欠き幅比より，土砂の捕捉率を推定する 二通りの回帰式を提示した。回帰式により， 分派堰の切り欠き幅や, 排砂対象となる流入 土砂の粒度分布が与えられれば，土砂の捕捉 率を簡易的に求めることが可能である.

今後，実際の排砂バイパス施設の検討の際に必要 となる混合粒径に対する分派特性を調べていく必要 がある。また，分派堰の施設形状についても，実際 のダムでの適用事例もある横越流方式に対寸る分派 特性について，今後検討を進めて行く予定である.

謝辞：（独）土木研究所水工研究部ダム水理チーム より，土砂バイパス施設分派堰水理模型実験に関す るデータの提供を受けた．ここに感謝の意を示す.

\section{参考文献}

1) 角哲也: ダム貯水池土砂管理の将来, 貯水池土砂管理 国際シンポジウム論文集, pp.117-126, 2000.

2) 川合茂,芦田和男 : 固定床開水路分流における流量 ・流 砂量配分比に関寸る実験的研究,土木学会論文集,No.405 ／II - 11,1989

3) 柏井条介,本田敏也,菅原崇之 : ダム貯水池の土砂バイパ 又施設分派特性,土木技術資料,No.37,Vol.12,1995

4) 原田稔,小久保鉄也,出野尚: 貯水池のバイパス排砂シス テムに関するトンネル内土砂水理特性,土木学会論文 集,No.600／II - 44,1998

5) 米山望, 永島弘士 : 複雑な移動・回転を考慮した津波 漂流物の三次元数值解析手法の開発, 海岸工学論文集, 第56巻, pp266-270, 2009.

6) 米山望, 井上素行 : 三次元数值解析による揚水発電所 貯水池内水温 - 濁質挙動の予測手法, 土木学会論文集, No.684/II-56, 127-140, 2001.

7) Bing-Yi Liu : Study on Sediment Transport and Bed Evolution in Compound Channels, 京都大学学位論 文, 1991 .

(2014. 9. 30受付) 